\title{
The Image: Disaffect in the theatre of representation
}

\section{Bridget Crone}

To cite this article: Bridget Crone (2010) The Image: Disaffect in the theatre of representation, Journal of Visual Art Practice, 9:2, 123-138

To link to this article: https://doi.org/10.1386/jvap.9.2.123_1

$$
\text { Published online: } 03 \text { Jan } 2014 .
$$

Submit your article to this journal $₫$

цll Article views: 60 


\section{The Image: Disaffect in the theatre of representation}

\begin{abstract}
This essay addresses the image as it appears in current contemporary art practice, principally through an examination of the work of Turner Prize nominees, The Otolith Group, as well as Hito Steyerl, Rabih Mroue, Gail Pickering and Tom Nicholson. Following an interest in the possibility of an image without a dependency upon a relationship with a human subject or viewer, the essay explores the consequences of the proposition that an image 'has a life' beyond representation. This question is addressed through the three parts suggested by the essay's title - first, the status of the image as being beyond representation but instead characterized by its operation and by its relationship to the event; second, the image as presence and the question of theatre as a process of intensification of the image's presentation and the accompanying experience of the image within the affective field; and finally to the question of disaffect. The essay ends with the proposition of disaffect as the reinsertion of the interval - the gap that is lost through the smooth space of affect. Disaffect is here a strategy for the curatorial to approach the question of the unbinding, the unraveling of the centrality of the subject within the representative order. And by contrasting Alain Badiou's notion of the event with that Gilles Deleuze, the question of the 'outside' is reintroduced as is, the essay argues, the subsequent unbinding of the centrality of experience to the curatorial project, therefore offering instead a focus on structure and on methodology rather than on the binding (of subject with experience, of experience with knowledge and so on) of affective processes.
\end{abstract}

\section{KEYWORDS}

image

affect disaffect representation participation subject human presence body Jacques Rancière Gilles Deleuze 
1. My reference to the image throughout this text crosses art and media culture with abandon and this lack of formalism is a deliberate one - I seek to be specific about the operation and the effects of the image in individual cases, and to speak in generalities while building impetus towards these specificities. Mostly, I am concerned to weigh up and wade through the differing current discussions and debates about the image and it must be noted that these debates do not concern the operations of semiology, for example, instead the relationship between the image as a sign or symbol and its referent are left alone in favour of a discussion of the image's actions and operations in relation to its role within representation and within a different all-pervasive system of affect or affective modulation, as Brian Massumi calls it, where the image operates (on us) on a bodily level so that signification lies not at the level of text or language but at that of a bodily, sensory response.

2. Otolith III is termed by the artists a 'premake' 'just a script in a drawer' - and therefore these images are themselves not yet realized. As the script states, 'We're not images. Not sounds. Not even fictions'. And elsewhere, Anjalika Sagar has stated: 'The figures of Otolith III are personifications of propositions' (The Otolith Group 2009: 113)
It is curious that while questions concerning the efficacy and operation of the image have dominated contemporary art production recently, much discursive focus has seemed intent on reasserting a kind of humanism to the image (in the loose sense of returning a human cause and concern to the image and its effects). Of course, it is rhetorical to pose the question of 'why this humanist (re) assertion and recuperation' seems so important, so necessary to debates around the image... Yet, at the same time, it does seem necessary to ask what happens if we address the contrary - investing our attention in an image that is without depth, might not bear witness, might not represent a citizen subject, might not be grounded in a connection with a thing, subject or object, and may exert its immersive power over us through and by our commonality of the sensible. So then, we begin this journey with the image at a point of recognition that there is a certain division, a certain tension, within the constitution of the image, and we recognize that this is characterized by the dialectic between the image as signification and the image as having a presence and effect. But rather than focusing on the well-rehearsed discussion of this dialectic, let us instead accept it as a given and add a third term - the condition of the image as operation, characterized by its flow, by the speed of its dissemination. This is the image taking its own life into account so that it is no longer grounded in a direct connection with a thing but is produced and reproduced as it flows through networks. With the image, we will proceed in a backwards movement through the three parts that comprise the essay's title (disaffect in the theatre of representation); starting from the image beyond representation, moving towards the question of theatre and the theatrical as a process of intensification then towards the image as the operation of affect. The question of 'theatre' arises as a problematic point that suggests both the desire for and the impossibility of an embodied presence. This is the crisis in spectatorship that Jacques Ranciere describes so well in The Emancipated Spectator - the desire for participation (for being wholly present or involved) and the representation of that participation, which necessarily involves a separation. As such, theatre can be seen as two contrary processes, that of making visible (therefore 're-presentation') and the impetus towards an embodied presence. Experience is the pivot around which both theatre as representation and theatre as presence revolve and the text turns to the experience of the image - in particular, the image's affective capacity. Here the image is a product of its effects and its operations - its flow, its dissemination and replication - and is characterized as such, not through its depth, its sacred capacity as the 'distinct', as Jean Luc Nancy would suggest, but through the very opposite. Following the work of Brian Massumi on fear, various possibilities for the dissemination of the image are explored - the image as networked, viral, cloned and airbourne. Reaching, exhausted, the depths of immersion (but oddly in a system without depth) we are subsumed by the exercising of a governmentality through and by the affective modulation of the image, we can begin to ask ourselves what disaffect might look like. ${ }^{1}$

\section{‘I WANT MORE LIFE’, SAYS THE IMAGE}

THE BOY confronts THE DIRECTOR to demand that he complete the unfinished film of which THE BOY is a kind of pre-image, an image imagined but not yet realized. ${ }^{2}$ THE BOY, he is an idea; an idea of an image, perhaps. Here, in The Otolith Group's film, Otolith III (2009) these pre-images appear through a voice-over and they demand 'life' - 
existing in limbo 'in the outer perimeters of Region Code 3 Protected', they 'dream of projection', 'of luminosity' and they take matters into their own hands to search out the human agents to fulfill their destiny as images. (The Otolith Group 2009: 45-47) I want more life, says the image. But how can an image have life? I want more life, says the image. But how are we to understand the image, this image that demands life?

It would be mundane to comment about the way we simultaneously 'appear' and ' $b e^{\prime}$ in the world - a process that invokes and combines a non-separation of the presence of our body in relation to others, and the various signs and significations that these bodies proffer to communicate - but less mundane to suggest that this process is akin to the operation of the image today. This is to suggest that there is a non-separation between the image readable as text and the image having a presence that puts into effect reactions beyond those that can be rationalized by the mind. Yet, the constitution of the image by or through a separation between text and appearance is a kind of mainstay of writing and thinking about the image. For example, the art historian, W. T. J. Mitchell constitutes the image as being composed of the dialectic between what he describes as the 'emblematic' and the 'expressive' image (Mitchell 2005: 291). This reduces the image to a form of iconography - a status that is dependent on the image's reception so that the expressive image is 'unreadable, mute, indexical' (to paraphrase) and akin to a primitivism prior to language, whereas the emblematic image is directly readable, linked to the word and of course representation. So that, unlike the image in The Otolith Group's Otolith III (the image that demands 'life'), Mitchell's image is intrinsically bound to the perceiver so that its constitution as image is wholly dependent on this perceiving subject or participant spectator. The limitations of this approach are apparent in Mitchell's work on the Abu Ghraib images, which he sees as icons - signs of the times, symptomatic and representative of the War on Terror. When these images first appeared in the press, Mitchell stated: 'I wrote to all my Art History friends, my iconological colleagues, and said: "let's archive, document, track down mutations of this figure, to begin to make sense of how the Abu Ghraib archive is constituted, can be understood, and analysed"' (Smith 2009: 332). According to Mitchell, a key element of this archive is Hans Haacke's Star Gazing (2004), which 'illustrates the US Army's 'interrogation practices' and a certain American mindset in relation to the War on Terror' (Smith 2009: 332). This photographic image of a faceless person, head covered by an orange hood, symbolizes and contains at a glance all that we already know about the US Army's tactics of containment, interrogation and terror - all in one neat package and it stops there begging the question: what can the image do other than stand and represent what we already know or suspect?

In direct contrast to Mitchell, The Otolith Group speak of opacity as a strategy for evading the direct readability of the image, and instead favoring an image that does not directly produce knowledge, that is, it does not simply represent a text, an event, subject or thing [...] In an interview about the work, Nerous Rerum (2008) - a film that confronts the 'conundrum' of representing Palestine - the artists, Kodwo Eshun and Anjalika Sagar, speak about their desire to avoid enabling a point of easy identification through the 'camera's vision', the point at which through narrative structure the eye of the camera becomes naturalized as one's own, and to instead return the job of looking back to the viewer. This project is partly achieved through 
the action of making apparent the production of the image through the Steadicam so that the image here is apparent as an operational process rather than the natural ally of experience. In this way, the mannered presence of the Steadicam (a hand-held camera fitted with a device that steadies it against the body) acts to dislodge the seamless passage of the image to the eye as a kind of smooth relationship between the experience of beingthere and representing the experience of being-there. Yet the intention here is not the constitution of the Steadicam as a kind of non-human gaze, but is instead to build a bridge that questions the relationship between viewer and subject and unsteadies the construction of an empathy (through narrative, through the image) on the part of the viewer: 'forming a bridge of nontotalising empathy between the two' (Demos 2009: 127). Eshun states that they wished to construct 'an opacity that seeks to prevent the viewer from producing knowledge from images' (Demos 2009: 123). And it is interesting to contrast this approach to that of Mitchell's reading of the use of the image both in Haacke's Star Gazing and the US Government's campaign of 'Shock and Awe' because as T. J. Demos suggests in the article, The Right to Opacity, the film undermines the 'division of appearance and speech into a hierarchy of signification, reproducibility, and dissemination, ranging from matters of urgent public concern to disregarded noise' (Demos 2009: 128). Therefore, the Otolith Group's strategy of opacity not only frees the image from being consigned to a role of signification by breaking the direct, transparent, representative role of the image (the problematic of 'speaking for the other'), but also addresses the hierarchy of the sensible (Demos 2009: 127, 128). Here Jacques Ranciere's notion of the distribution of the sensible where we are in common through a shared condition of sense, yet divided through a hierarchy of distribution based on a division between 'those who have a part in the community of citizens' - that is, a division between the 'modes of being and forms of visibility' - is addressed (Rancière 2004: 12, 13). As Anjalika Sagar asks:

Is it possible for the dispossessed, for those that have little or no capacity for self-appearance, for those that have no space to be visible in the global distribution of the sensible, is it possible for these subjects to appear as other than victims or witnesses?

(Emmelhainz and The Otolith Group 2009: 129)

The Otolith Group's approach to the image as operation - through the example of the Steadicam in Nerous Rerum, for example - and their exacting approach to the specific operations of individual images enables both the condition of opacity and the possibility of readdressing a hierarchy of distribution. This focus on operation can also be seen in a different way in Otolith II, where Eshun has described the strategy that they used during filming in Dharavi (a slum area in Mumbai), that is, instructing their cameraman to film individual people labouring for the duration of their work, so that:

(I)f one boy embroidered the hemline of a sari for ten minutes, then Garagey would film the boy for that same duration of ten minutes. The proposition was to transfer the duration of labour to the weight of the image which would then begin to register the effort of the hand-held frame.

(Otolith 2009: 95) 
Here the intention is not only on the process of 'making visible' (a process aligned with the politics of identity where visibility is both the start and end point of enquiry - the point of 'here is' or 'here I am') but is instead an attempt to readdress the operations of image-making so that in this case the focus on the material labour of the camera enables a readdress of Ranciere's distribution of the sensible between those who have a part and those who have none. As Eshun states, '(T)he experiment we tried to carry out was to evoke the affective dimension of production by making the camera bear the labour of looking for as long as the sweatshop teenagers themselves' (Otolith 2009: 95). It is the invention 'of ways to subtract the image from the narrative that it supports and thereby, perhaps turn the demand back upon itself' (Emmelhainz and The Otolith Group 2009: 132). So it is the Steadicam that moves through Jenin; it is the Steadicam's presence that the residents of Jenin ignore or barely acknowledge as they go about their daily business. Yet the Steadicam does not seem like an uninvolved eye or a clinical appraisal or measurement under the guise of 'objectivity' or the distanced reportage of the news corporations; it actually seems quite vulnerable at times as it is caught up in the events unfolding around it. And the mechanics of the Steadicam, which is worn and steadied against the camera-person's body, should be remembered as a contrast to that of a camera trolley or truck and therefore introduces an instability of a point of contingency resulting from the presence of the body in relation to the machine of the camera. The effect of this process is a material image - an image that is intrinsically connected with the nature of its production. As T J Demos rightly suggests, The Otolith Group's strategy of opacity unpacks the hierarchy of 'forms of appearance', by inverting the hierarchy of its operations - 'signification, reproducibility and dissemination' - so that signification is rendered as production (the labour of the image suggested above), reproducibility and dissemination are temporally disorientated so that the pre-images seek the means for their own production or realization of images (think of the scenes in Otolith III where the pre-images seek agents for their realization - 'THE INDUSTRIALIST: This boy could play the part of THE BOY. Or this one could. No, he's not right' (The Otolith Group 2009: 52) and therefore seek their own agency, 'more life'.

Creating a disjuncture in this hierarchy or 'distribution of the sensible' and the rupturing of image from the safe haven of an established relation to signification and reproduction is territory also explored by Hito Steyerl in her film November (2004), which combines images from differing registers, temporalities and with differing operations. Constructed from distinct sets of footage - one being an unfinished Super 8 film (in the style of Russ Meyer, Faster Pussycat Kill Kill (1965)) that Steyerl made with her friends in the late 1980s, the other footage exploring the martyrdom of Steyerl's friend, Andrea Wolf, the leading protagonist in the aforementioned film. These two sets of footage are distinct through their temporal and material difference. The super 8 film has a material register - the graininess of the image, richness of the colour-field - that is filmic and coupled with the stylistic overtones of its trashy content and that claims it as film-fiction. The other set of footage explores the story of Andrea (a childhood friend of Steyerl's), who joins the PKK in Northern Turkey where she is killed by the Turkish army fifteen years later. This footage pieces together Andrea's death (narrated by Steyerl), and is collated from TV news reports and crucially from a PKK protest poster bearing the image of Andrea, the martyr. The material register of this latter footage is very different - the sound of the VHS cassette sliding into the machine then the image framed 
3. In fact, the 'truth' of Andrea's story could be questioned given that the film begins with a type of fiction - that of adventures of Andrea as feminist avenger as appears in the Super 8 footage of Steyerl's first film shot in 1989 - and as a result of Steyerl's declared interest in the processes of truth and the documentary form. within the template of a news report along with the home-movie style video of Steyerl on the PKK march registers it within a personal realm. We are led through the film November by the image on two counts - the image as 'material' in which we are directed by the image's material register, and the image as affective, where the image of Andrea's face operates in place of a narrative structure so that the centrality of the image of Andrea's face (which appears in an array of sites and locations) is discovered by the camera and narrated by Steyerl. The fact that the image of Andrea and the focus on the image itself is not in terms of what takes place within the single image but what occurs in the space between the accumulation of image - that is the space between image and image - points to what Deleuze terms the affection-image in his book on cinema, Cinema 1: the movement image (2005). Deleuze sites the affection-image in relation to the face by stating, 'the affection-image is the close-up, and the close-up is the face' (Deleuze 2005: 89). The face therefore 'gathers and expresses affect' and it does so through the close-up. Yet it is not individuated but rather it is a 'complex entity' made from the 'virtual conjunction of singularities' so that the close-up of a face - while a realization or activation of affect through the expression that the face bares - is a kind of process of deterritorialization; it is emotive and empathetic because it signals recognizable expressions of fear, love, wonder, for example, but is active as an operation that moves us through the assemblages or accumulation of images rather than remain stuck within the signifying force of an individual image. In November, the search for Andrea seems to be at once an exploration of the possibility for documentation of an individual history through the image, and in this way it is a sketching out of the processes of documentary form in itself in terms of how and what the image can tell us - that is its potential power. The image that leads this search is an image of potentiality - not only does this image have the potential to show us or to tell us of Andrea's history fragments or pieces of a puzzle that are pieced together by Steyerl - as an assumed singular 'truth' about her life as she lived it, but it also has another kind of potentiality in relation to fiction because at no point do we actually know the 'truth' of Andrea's story or indeed her existence. Instead, the image or the close-up stands as a kind of verification with the material authenticity of the image - the grainy, muted colour of the Super 8 footage, the fallingapart, degraded image from the VHS cassette - activating this process. ${ }^{3}$ The image in November therefore comprises two aspects, that of potentiality and of power - where the actualization of the sensation determines its 'quality' - and the potentiality of the sensation its 'power', so that Andrea's image - the face, the close-up - directs the unfolding of events that determines this power.

Here we have an image that's not simply tied to a materiality but to a space of potentiality - particularly in the work of the Otolith Group where the image can be seen as Deleuzian event - 'infinitely generative' and 'viewed with potentiality' - and it is this image-as-event that allows further consideration of the possibility for the image to exist outside of a dependency upon the viewer. And, it is at this same point that I would locate the image that demands 'life'. This is a precarious state of causality and separation where the event is caused by the 'actions and passions of the body', and at the same time, it is not reducible to this causality because the paradoxical, excessive and aleatory intervene to assure the 'full autonomy of the effect' (Deleuze 2004: 109). That is to say, affect is beyond the emotional (that is, beyond the emotional reaction of the subject) because as it comes into being it has a life that is separate or in-excess of the 'actions and passions of the body' that excited 
it into being - as Deleuze and Guattari write in What is Philosophy, affects are 'no longer feelings or affections; they go beyond the strength of those who undergo them' (Deleuze and Guattari 1994: 164). This is the point at which the image as affect stands independently from relationality, and like the Otolith Group's strategy of opacity, it is not completely severed from this ground but 'stands up on its own' (Deleuze and Guattari 1994: 164). This independent image separated as it is from its relational grounding finds some resonances in Jean Luc Nancy's idea of the image as sacred, as distinct and which, as a result of the continual process of separating itself from its ground, becomes imbued with a violence. The image's violence is the violence of self-presentation because in order to be present, the image must enter into a conflict with the thing (as the presence of the image is dependent on the absence of the thing) and undertake a violent birth in order to separate itself from its ground in order to be seen as distinct (or present). 'The image is the imitation of a thing only in the sense in which imitation emulates the thing: that is it rivals the thing, and this rivalry implies not so much reproduction but competition, and, in relation to what concerns us here, competition for presence' (Nancy 2005: 21).

\section{PRESENCE}

The split in the nature of the image, as W. T. J. Mitchell has suggested, between the 'expressive' and the 'emblematic' (or in other words, between the image as having an expressive efficacy that is beyond the literal and the image as a symbolic operation) finds equivalences in the dialectic that lies at the heart of theatre. This is, of course, the tension between the being-there of 'pure presence' and the representation or staging of that presence. In The Emancipated Spectator, Jacques Rancière writes of this difference being exemplified in the opposition between drama and theatre where '(D)rama means action' and theatre demands a spectator that is by definition, passive, and Rancière suggests that this division must be overcome (Rancière 2009: 3). Here the energy invested and generated through the action or drama of performance is all-involving - it seeks to achieve a pure unmediated presence in the present moment - whereas theatre occupies a different set of temporalities (in which the 'moment' is always deferred), and it represents the action of the subject before an audience of spectators. Therefore, the represented moment of staging refers to a present (and a presence) that is never unmediated - it is never able to be purely in the moment - whereas the goal of action is absolute involvement. So what does this mean for the image? Here we see the split played out as between the image as 'affect' - as able to invoke reaction through being present in the moment with other bodies, for example - and this is contrasted to the image that stands in for 'the word' describing actions and passions that have taken place or might take place in the future. As Rancière states, this is the classic opposition between actor and spectator, between absolute involvement and the exteriority of the spectator:

Reformers of theatre have reformulated Plato's opposition between choros and theatre as one between the truth of the theatre and the simulacrum of the spectacle. They have made theatre the place where the passive audience of spectators must be transformed into its opposite: the active body of a community enacting its living principle.

(Rancière 2009: 5) 
We have seen this tension between theatre and spectacle, true experience and simulacrum played out through the use of the tableaux vivant within contemporary art practice over the last few years - the utilizing of overlapping and overlaying components of live performance with video or of a photographic image with live music, would be two examples of this practice. The British Artist Gail Pickering's work, Brutalist Premolition (2008), is a case where the difficulties of the image to represent make way for a live performance that itself plays-out stated fictions so that layering and repetition allow the work to enter into a process of reformulating (or at least questioning) the established relationship between the 'truth of the theatre and the simulacrum of the spectacle' or vice versa. Brutalist Premolition is both a film and a performance that takes place within a sculptural set. The work arose from a curiosity about the way in which architecture might impact on bodies (the work is set in the infamous Robin Hood Gardens Estate in East London, designed by Alison and Peter Smithson and completed in 1972, proponents of New Brutalism in Britain; the estate was slated for demolition in 2008 but currently remains standing) along with questions about how an artist might represent the experience of these bodies without assuming the role of narrator, participant or of witness, and a desire to neither facilitate a spectacle, claim a position of false allegiance or remove. Pickering's solution to these questions is to invite a resident family to cast actors to play themselves in the subsequent film, and she allows us to see the communication between the actors and non-actors unfold. This footage is then interspersed with that of the actors repeatedly reading (rehearsing?) lines from their parts at different points throughout the flat. This action is then mirrored in the actors' performance in the sculptural set so that the unfolding in 'real' time punctuates and is punctuated by the film-action that is also projected within the set. The effect of this doubling and layering combined with the audience roaming freely around the performers is a constant layering and repetition that serves to unmask our presence and involvement in the 'liveness' of the performance and the mediated document that is the video-image. Yet despite the continually repeated staging of the actors' performances and their interactions with the flat's residents, the result is not a smooth narrative-driven revelation of a truth (or of a fiction) but rather, a kind of intensification of the component parts and complications between each of them - our underlying expectations of presence in the moment and the spectacle of staging presence.

In Brutalist Premolition, there is not so much a violent conflict between the presence of the image and the presence of the thing as Nancy suggests but an assemblage of layering of both at once, leading to a process of intensification. The image as a presence that enters into a process of intensification or accumulation through its very appearances and movement could be proposed through the work of Australian artist, Tom Nicholson - Printed Pages (Bearing Images) (2008), and Nancy too plays with this idea of the image as an intensity that presents itself. Nicholson's film is formed by a massive collection of still images - accumulated by the artist over a ten-year period - that are animated through the processes of montage and dissolve. Within the constant movement and evolution of the image in the work - in which image merges into image through the dissolve and the transparency of the paper held aloft images seem to generate each other in a self-replicating cyclic world. As Nicholson writes, it is a case of 'images proliferating images; an insistent but shifting relation between the image and animation; and the confusion, merging and/or conflict between the faces that bear and the faces that are borne, 
between culprit and victim' (http://www.tomn.net/nicholsontextonprintedpagesbearingimages19982008.htm Accessed 18 January 2010). Despite the obvious symbolic capacity of the image within Printed Pages, the operation of the image seems not to be to represent or to connect to a world outside of the logic of its own movement, its flow so that the concentration of activity upon this process causes a kind of evacuation of space around it. Nicholson proposes that this process of dominating and of taking up space is akin to that of the monument. He writes that the work:

[...] engages the monumental through what I would describe as its 'gathering up'. This encompasses both a spatial characteristic (the way the monument situates itself at a point where sight-lines align, crowds accumulate, stairs rise, in short moments of visual climax in the city's spaces) but also a procedure (that of bringing together, massing together, unifying, reconciling, totalising, or conversely, reducing the diversity of human action to two categories).

(http://www.tomn.net/nicholsontextonprintedpages bearingimages19982008.htm. Accessed 18 January 2010)

Yet at the same time, Nicholson also claims that the work is involved in a complex process of undoing - 'because of the endless dissolve mechanism' so that while it 'gathers up' it is also involved in a process of undoing. And this undoing - the fragmentation and dissemination of the image - made and remade through the processes of layering and of dissolve also form the structure of the work so that while consisting of 198 separate images, these images when spread across 144,000 frames become multifarious and seemingly endless in variety, repetition and movement.

At what point does this image - which following this logic is in constant movement as it is downloaded, uploaded, compressed, recompressed, processed, reprocessed - become separated from its relationship with a human subject and become simply a piece of digital information, a series of zeros and ones $(0,1)$ flowing through a network? Nancy suggests that the image is involved in an operation of intensification that is predicated on an absence (of the thing), but crucially he distinguishes between the image's operation in relation to representation as 'exposing its value or sense [Õ] of being there before a subject' (Nancy 2005: 36). But alternatively could the image travel as a bunch of effects - an assemblage of affects - travelling through and over high-speed digital networks that enable it to produce and reproduce itself through its movement, constituting a world of its own and with its own governance and internal logics? The work of Lebanese artist, Rabih Mroué, seems to suggest this type of possibility. Mroué's Inhabitants of Images (2009) is a performance work comprising an artist's lecture with accompanying visual information. First performed at the opening of the Istanbul Biennial in 2009, Inhabitants of Images is an ironic exploration of propaganda posters that he finds on the streets of Beirut, and which leads Mroué to propose that once people have died they live inside images and are able to inhabit images of their choice, that is, they can swap from image to image should they so wish. In this way, Mroue outlines a possibility in which images form their own worlds with their own internal logics and narratives - for how else could (Egyptian Prime Minister then President, 1954-1970) Gamal Abdel Nasser and (Lebanese Prime Minister, 1992-1998 and 2000-2004) Rafic Baha El Deen Hariri meet in the same image? This becomes the central subject of Mroué's lecture - a 
4. The alerts were green low, blue - guarded, yellow - elevated, orange - high, and red-severe. kind of detective tale about the way in which images are able to play tricks on us, the viewer in which he inspects the image - no sign of montage, no sign of clever Photoshop work, he claims - how could this be? The examination of this problem leads Mroue to conclude that the inhabitants of images must have their own life and therefore also agency to choose which images they inhabit and who they inhabit them with ... after all, what's the alternative here? To distrust the image and suggest that we aren't in fact seeing Nasser and Hariri standing together? To suggest that the image is false? Not only is Mroué's work about the operation of the image in documentation or representation but also present in his work is the thin veneer that stands between life and death itself so that the dead are always somehow present (or in this case intermingling in some kind of photographic afterlife). And Mroue has suggested that this movement between life and death is present as a condition of Lebanese daily life. So that in the performance, How Nancy wished that everything was an April Fool's Joke (2007) and similarly in Three Posters (2000, 2004), death is at once present and mediatized by the camera. Mroué writes:

The dead here do not leave, or more truthfully the inhabitants of the city refuse to allow the murdered to go on their way and they bury them at home. The realms of the living and the dead are intermingled. The cemetery is inside the house and the coffin lids are open. The dead fill time and space with their comings and goings, and the dead begin to live with us [...] Everyone is killed and alive in his/her community, and communities speak for the dead. We can no longer differentiate between the words of the dead and the words of the living. It is as if the weapons of a community are its slain and its dead.

(Hiddleston 2008: 51)

\section{SPEED EFFECTS}

What might be the consequences of this image that is able to travel, to have a presence, to demand its own 'life'? And in relation to the operations of affect might an image operate akin to a body that produces and is produced through its movement, its operations? In his essay Fear (the Spectrum Said), Brian Massumi outlines a situation through which the image in the crudest sense - in this case the traffic light-like graphic of the terror alert system and its colours of red, orange, green and amber - is able to enact governmentality through a process Massumi calls, 'affective modulation'. Through the operation of 'affective modulation', Massumi explores the exertion of power by the US Government through its system of terror alerts that 'modulate the intensity of collective feelings' through the twin operations of perception and affect, and the organising/controlling potential of colour coded terror alerts (Massumi 2005: 31). As anyone visiting or living in the United States in the years post 9/11 would remember the code seemed to remain 'redward' and as Massumi points out: "Safe" doesn't even merit a hue. Safe it, would seem, has fallen off the spectrum of perception' (Massumi 2005: 31). The affective modulation achieved through the 'perceptual cues' of the alert system was less to induce fear as to control it. The alert system was used to 'calibrate the public's anxiety' so that it didn't 'swing out of control', and therefore could be controlled by the government, as an almost form- and contentless perceptual control (Massumi 2005: 31). Yet while fear and anxiety were useful tools for governmentality post $9 / 11$, they carried with them a degree of 
risk - the risk that fear itself would be exhausted and the risk that its modulation would be untimely and disruptive and therefore the real problem became how to control the individual variables of affect - that is the way in which individual bodies perceive, process and deal with threat and fear differently. So, as Massumi also observes, while television - the pre-eminent 'privileged channel for collective affect modulation in real time, at socially critical turning points' - offered a means of remaking the link between governmentality and representation, what it offered in terms of immediacy it did not always deliver in terms of reliability, and, so, the terror alert system became an important way of safeguarding against these variables. Massumi states: 'a political uncertainty is established. It practically acknowledges that the systematic environment within which power mechanisms function is metastable, meaning provisionally stable but excitable, in a state of balance but ready to jog' (Massumi 2005: 35). Therefore the link between television and the affective mechanism of the terror alerts became an essential tool for the US government; 'Without proof, without persuasion, at the limit even without argument, government image production could trigger (re)action' (Massumi 2005: 34).

This is therefore an image that no longer represents a subject, object or thing, but instead it sets into motion a response that is bodily, a physical sensation of fear or of panic. While this response is stimulated through a visual process - a bodily reaction linked to a particular colour-code - it is not isolated to the particular sensing mechanism as Steve Goodman's work on the sonic effects of war (Sonic Warfare, 2009) illustrates. Rather it is the viral and all-pervasive dissemination - the movement - of affect that is the point here and one is mindful of Jean-Luc Nancy's suggestion that the image is no longer limited to the realm of vision, but instead the image 'throws in my face an intimacy that reaches me in the midst of intimacy - through sight, through hearing, or through the very meaning of words. Indeed the image is no longer visual; it is also musical, poetic, even tactile, olfactory or gustatory, kinesthetic and so on' (Nancy 2005: 4). Here the image is rendered without depth - with no inside or outside but is instead a 'cojoining of sensing and to be sensed' - and is therefore dependent on an intimacy of reception (Nancy 2005: 11). As Nancy states, the image belongs not 'to the domain of objects, their perception and their use, but to that of forces, their affections and transitions' (Nancy 2005: 12). This image that is produced through the terror alert system therefore operates through the modulation of a bodily responsiveness, and is an operation that goes beyond representation circumventing the necessity of addressing form or content in order to appeal to a collective on the level of a 'common sensorium' resulting in a 'community of the sensible', and in achieving this, Massumi points out the importance of the 'formlessness' of power - pervasive and 'contentless' and which 'no longer has an object. It means that the object of power is correspondingly formless and 'contentless' post governmentality has moulded itself to threat' (Massumi 2005: 35). This exercising of threat through the modulation of the image occurs at what Massumi calls the 'pre-individual level': this is not to say that this takes place prior to the individual but 'at the limit between the subject and the world, at the limit between individual and collective experience' (Massumi 2005: 46). The relationship between image, affect and the production of subjectivities is at this point a somewhat sinister one - so that where affect is often articulated as having a positive micro-political potential as a means for understanding the emergence of new subjective forms through the collective workings of affect, it is here a somewhat sinister controlling device that involves us on a bodily, 
pre-individuated level. The emergence of a thinking of affect in relation to governmentality, to social control has emerged through the work of Massumi and others such as Steve Goodman and Steven Shaviro. Goodman, for example, uses a range of terms to describe the operations of affect in relation to forms of social control (sonic warfare): Affective tonality, Affective contagion, Uneasy listening, Affective tone, Positive and negative affective tone, Sonic toxicity, Sound as gas or perfume (after Brian Eno), Impression management, Mood contagion, Feeling tone (Goodman 2009). It is important to remember that the operation of the image as affect is both generative and generated through its participation with the bodies, subjects, objects, and things that it comes into contact with - this is not control without participation. As Shaviro writes:

But they are also productive, in the sense that they do not represent social processes, so much as they participate actively in these processes, and help to constitute them. Films and music videos, like other media works, are machines for generating affect, and for capitalising upon, or extracting value from, this affect. As such, they are not ideological superstructures, as an older sort of Marxist criticism would have it. Rather, they lie at the very heart of social production, circulation and distribution. They generate subjectivity and they play a crucial role in the valorisation of capital. Just as the old Hollywood continuity editing system was an integral part of the Fordist mode of production, so the editing methods and formal devices of digital video and film belong directly to the computingand-information-technology infrastructure of contemporary neoliberal finance. There's a kind of fractal patterning in the way that social technologies, or processes of production and accumulation, repeat or 'iterate' themselves on different scales and at different levels of abstraction.

(Shaviro 2010: 3)

\section{DISAFFECT: A SHORT NOTE ON CURATORIAL ACTION}

Throughout this essay, we have travelled between the binding actions of affect and the various processes acting towards an unbinding of the established modes of the image in relation to signification (that is representation) and dissemination, and, I would suggest, the attempted severance of a dominating relation with the human subject (the relation that Quentin Meillassoux has termed 'correlationism'). Rather than the contradiction of a world in which everything is produced and producing in the moment of encounter and which therefore defies the possibility of an outside - of a past or a future - this act of unbinding has the effect of revealing the fragility of this subjective (or correlationist) relation. Alain Badiou has used the term 'expressive dialectics' to refer to the lack of interval resulting from the correlationist circle - experience producing knowledge producing experience producing [...] and etc. - using it to describe the point at which there is no separation between the action and the effects of the political, so that the revolutionary politics of the last century have been replaced by 'moments', and so he states: 'political struggle and insurrrection, revolution, and so on, in the classical conception too: they are moments' (Badiou 2005). In contemporary art practice, we have seen this action of unbinding as a severance of the image's dependency on the subject, object, thing and, at times, the spectator. For many artists this action of unbinding has proven fertile ground for the accompanying action of a re-binding of alternate social 
relations and activities - for example, Hito Steyerl's suggestion that the poor image could engender new forms of collectivity through the image's distribution - so that the endpoint is not necessarily a post-human one. Similarly, the Otolith Group's strategy of opacity is the disruption of the strict adherence to subject relations so that rather than activating a 'naturalized' empathy through the narrative drive - activated through a learnt representative order, perhaps - this ordering is readdressed and laid open as a ground for something new to emerge. As Eshun has stated: '(P)erhaps the only way to render abstraction is to invent ways of separating images from words, images from bodies and words from sounds, and then to find a way to disjunctively reconnect them' (The Otolith Group 2009: 114). This act of separation, displacement and disjuncture in relation to the image is a crucial strategy as we have seen, and it is one that has the effect of reinstating the interval in contrast to the expansionist structure of affect. Again as Eshun has suggested, 'separating images from words, images from bodies and words from sounds' (and elsewhere in terms of the act of 'forging' (from component parts) rather than 'feigning' a reality) is the act of focusing on the separation (and construction) of parts in contrast to the smooth production of affect (The Otolith Group 2009: 114; Demos 2009: 121).

The implications and the force of the opposition between, on the one hand, a focus on the production of gaps, displacement, disturbance and disruption and, on the other, the smooth, expansionist movement of affect can be sketched as the difference between a Deleuzian notion of the event and that of Badiou. Put bluntly, this is the difference between the event as an unlimited becoming and the event as an interruption that brings irrevocable change. In his critique of Deleuze's conception of the event, Badiou traces its foundations in Jean-Paul Sartre's proposition of 'an impersonal transcendental field', the proposition of which he cites as a common preoccupation for both himself and Deleuze. However, Badiou suggests that both Deleuze and Sartre are unable to fully theorize the transcendental because they cannot separate it from selfconsciousness (Sartre) and the subject's becoming (Deleuze), in other words Badiou's - they cannot 'expose the subject to the chance of a pure Outside' (Badiou 2009: 387). And this 'outside' is the event - that is, the void, the inexistent, the errant, and excess that propels the event into being. So therefore, unlike Deleuze, the event for Badiou is a momentous force that surges forth (often he says it surges forth from outside, or surges up from below) from outside rather than a series of 'unlimited becoming[s]' that occur as the 'concentration of the continuity of life' (Badiou 2009: 382). For Badiou the event is a cut; it is a rupture and it is absolute change, and while it is difficult to understand the factors that bring Badiou's event into being, it is his clarification of his position in relation to Deleuze and his focus on the importance of an outside, his work on the transcendental in relation to the 'logic of worlds' and his use of mathematical set theory that provides our greatest clue. Badiou's focus on the structures and the logics of the appearance in worlds provides a logic that shifts the pivotal point of causality from a focus on the subject and instead offers a point at which the force of change external to the subject's self-expression may be expressed. That is to say, a world appears relative to the bodies, subjects, multiplicities, and things that appear within it - there is a reciprocal and interdependent relation present here but absolutely not a kind of continuous, enveloping causality centred around the subject. Translated simply into praxis, it could therefore be suggested that Badiou's logic motivates for us an interest in the exercising of structures, systems, logics and ordering, providing 
an alternative to the expansionist field of affect that is not strictly its opposite in the sense of alienation but instead poses a complex proposition for the interrelation of parts beyond the bland causality of experience, effect, knowledge.

If affect is akin to correlation - the production of bodies in relation to other bodies in a loose derivation of Spinoza, or the bodily, physical feeling that prioritizes emotion or feeling over thinking or the mind - as a naturalized expansionist structure could then disaffect be proposed as an emphasis on an excess of structure? If affect is understood as dependent on the experiential, then disaffect as non-feeling or disjuncture cannot be an alternative because of course this would simply respond to and prioritize its declared opposite, affect. However, if we adjust our thinking of disaffect as the open possibility of an abstract structure that rather than co-joining objects, people, things through the pantheon of experience then this emphasis on structure holds some real possibilities, particularly in offering the curatorial a strategy to engage in the disjunctive processes of unbinding, of reinstating the interval. And the current interest in accentuating structure in the form of methodology and methodological process is the curatorial equivalent of strategies such as those of Hito Steyerl and the Otolith Group - strategies that have sought to unbind the relationship between image, subject, knowledge, for example. This is not a focus on process but on organizing principles, therefore representing a shift from the coming to being to the logic of appearance - that is, a shift from exhibition-making as a process to exhibition-making as a methodology or as a structure, and similarly the focus on the use of text both by artists and as an inherent part of an exhibition structure must be considered in the same way as providing a curatorial structure for the examination of this logic of appearance. As Marshall McLuhan writes in The Medium is the Massage, this is the workings of text - principally the alphabet - outside of semantic meaning but instead appearing as a form that must be 'strung together in a line, bead-like and in a presumed order' (McLuhan [1967] 2001: 44). And this sense of words or text having a form that can be separated or divorced from meaning and instead used (at times nonsensically) as a kind of objective material with a shape, rhythm, form can be seen in much of the artists' work presented in a series of events - performances and readings - that took place at the Arnolfini in Bristol in June 2010 under the title A theatre to address. A theatre to address included works by a group of mainly London-based artists such as Annabel Frearson who is engaged in the rewriting of a contemporary interpretation of Mary Shelley's Frankenstein that uses all and only the words from the original so that the words rather than being imbued with a signification and meaning are divorced from this original context and, like McLuhan's alphabet, they are strung together, sorted into a new order. These architectures of textual form call into question the problems of representation by entering into a process of questioning the dominant narratives of language or of history through the use of formal devices (such as the theatrical) or recognizable visual and sonic forms as its material. And as a curatorial project this was, for me, specifically a question about finding strategies for resistance within the constantly flowing and changing field of affect through a focus on text not as a signifying, representing force nor as an affective operation seeking to bring together a community of listeners or conversants but through attention to structure and to the abstract ordering facility of text.

Disaffect then as a strategy for the curatorial is not about the experience of the work but like the image, the focus is on its operation, and this is approached through attention to its structure and structuring. This is not structure in a structuralist sense involving all of the straightforward intricacies of cause and 
effect nor is it about imposing an abstract order of things nor is it the aestheticization of abstraction through structural form. This is a strategy that focuses on the structure as a kind of ground, a ground of potential. This is akin to what the script offers Otolith III; somewhere between a realized and unrealized form, it enables the emergence of images - THE BOY, THE INDUSTRIALIST, THE JOURNALIST, THE ENGINEER and so on - from its framework. Here the script - Satyajit Ray's original script for The Alien - is present as an open potential, an open possibility that is not bound to an audience for its life (having existed unrealized for 40 years now) and therefore the images emerge to demand, to search for, their own form. As Jacques Rancière proposes through his concept of the sentence-image, the image and text are now 'unbound' from their interdependency and the result of this unbinding is the provision of a series of parts that can in turn be rebound. Rancière proposes the term, 'sentence-image' as a 'form of measurement' for this act of rebinding, and therefore the sentenceimage, is not only manifested in or through the space between image and text as a potent third (in an operation similar to that of montage) but it is brought about through rhythm, or rather a rhythmic structuring that gives it form. And so, I would suggest, this focus on rhythm as a structural property and a kind of ordering system is a key strategy for approaching - with a letter of polite invitation - the image in contemporary art practice today.

\section{REFERENCES}

Badiou, Alain (2005), A Non-Expressive Dialectics (Saturday 26 November 2005, Birkbeck Institute for the Humanities, London. Transcribed by Robin Mackay), Urbanomic.

Badiou, Alain (2009), Logic of Worlds (trans. Alberto Toscano), London and New York: Continuum Publishing.

Chandler, James (2010), 'The Affection-Image and the Movement-Image', in D. N. Rodowick (ed.), Afterimages of Gilles Deleuze's Film Philosophy, Minneapolis and London: University of Minnesota Press, pp. 235-258.

Deleuze, Gilles and Guattari, Felix (1994), What is Philosophy? (trans. Hugh Tomlinson and Graham Burchill), London: Verso.

Deleuze, Gilles (2004), The Logic of Sense (trans. Mark Lester), London: Continuum.

Deleuze, Gilles (2005), Cinema I: The Movement-Image (trans Hugh Tomlinson and Barbara Habberjam), London: Continuum.

Demos, T. J. (2009), 'The Right to Opacity', October, 129, Summer 2009, pp. 113-128.

Emmelhainz, Irmgard and The Otolith Group (2009), 'A Trialogue on Nervus Rerum', October, 129, Summer 2009, pp. 129-132.

Goodman, Steve (2009), Sonic Warfare, Massachusetts: MIT Press.

Hiddleston, Anna (2008), 'Rabih Mroué', in The Anxious: Five Artists under the Pressure of War [exhib. cat], Paris: Espace 315, Centre Pompidou.

Massumi, Brian (2005), 'Fear (The Spectrum Said)', Positions, 13: 1, Spring 2005, pp. 31-48.

McLuhan, Marshall ([1967] 2001), The Medium is the Massage: An Inventory of Effects, Corte Madeira: Gingko Press.

Mitchell, W. T. J. (2005), 'The Unspeakable and the unimaginable: word and image in a time of terror', ELH, 72: 2, Summer 2005, pp. 291-308.

Nancy, Jean-Luc (2005), The Ground of the Image (trans. Jeff Fort), New York: Fordham University Press. 
Rancière, Jacques (2004), 'The Distribution of the Sensible: Politics and Aesthetics', in Rancière, Jacques, The Politics of Aesthetics (trans. Gabriel Rockhill), London and New York: Continuum, pp. 12-19.

Rancière, Jacques (2007), The Future of the Image (trans. Gregory Elliot), London and New York: Verso.

Rancière, Jacques (2009), The Emancipated Spectator (trans. Gregory Elliot), London and New York: Verso.

Shaviro, Steven (2010), 'Post-Cinematic Affect: On Grace Jones, Boarding Gate and Southland Tales', Film-Philosophy, 14: 1, pp. 1-102. http://www.filmphilosophy.com/index.php/f-p/issue/view/14 Accessed 31 August 2010.

Smith, Marquand (2009), 'Politics: An interview with WTJ Mitchell', Culture, Theory and Critique, 50: 213, July 2009, pp. 321-335.

The Otolith Group (2009), A Long Time Between Suns, Berlin and New York: Sternberg Press.

\section{SUGGESTED CITATION}

Crone, B. (2010), 'The Image: Disaffect in the theatre of representation', Journal of Visual Art Practice 9: 2, pp. 123-138 doi: 10.1386/jvap.9.2.123_1

\section{CONTRIBUTOR DETAILS}

Bridget Crone is a curator, writer and lecturer working in London and South West England. She is a freelance curator and currently the Artistic Director of Media Art Bath - a publicly funded commissioning organization that champions contemporary art and ideas through the development of bold new work collaborating with artists and partners locally, regionally, nationally and internationally. Recently, Crone has worked with artists such as Gail Pickering, Pil and Galia Kollectiv, Clare Gasson, Tom Nicholson, Juneau/ projects, Melanie Gilligan and Maryam Jafri to produce bold new work across the fields of performance, installation, sound, as well as film and video. And she has taught at universities including Goldsmiths, University of Kent and Chelsea School of Art and Design, University of the Arts London where she contributed to the MA Critical Writing and Curatorial Practice (2007-10).

Crone's curatorial work can be typified through its enquiry-based approach working through an engagement with both ideas and practice. Examples of this practice can be found in her work such as the conference, Imploded action, dissonant affects: Towards a new politics of non-relationality?, which she convened with Amanda Beech and Marie-Anne McQuay (2010) to explore anti-humanist impulses in current contemporary art practice; and also in her ongoing curatorial research projects, A theatre to address: a festival of textual form-concrete, material, scripted and performed (2010) and The Sensible Stage (2008-9), which each take a radically difference position from which to address ideas of affect, participation, staging and performance.

Bridget Crone is a Phd candidate in the Department of Visual Cultures, Goldsmiths, the University of London.

E-mail: bridget_crone@mac.com 